\title{
KÍSÉRLET EGY RÉGIÓ SZIMULÁCIÓS MODELLJÉNEK KIDOLGOZÁSÁRA
}

\author{
(An Attempt to Build up a Simulation Model of a Region)
}

\section{SMAHÓ MELINDA}

Kulcsszavak:

regionális input-output modell tovagyürüzö hatások területi fejlödés

A területi szerkezet és a területi folyamatok elemzésére korábban széles körben alkalmazot regionális input-output modellek fénykorát követỏen a területi kutatásokban is új elemzési eljárások jelennek meg. Ezek egyike a komplex rendszerek elemzésére alkalmas szimulációs modell. A tanulmány célja egy, a területi fejlödés vizsgálatára kísérleti jelleggel kidolgozott szimulációs modell bemutatása, továbbá a modell müködésének, felépítésének és a modellezés tapasztalatainak az ismertetése.

\section{Bevezetés}

A területi szerkezet, a területi folyamatok modellezésének történetében a regionális input-output modellek kidolgozása és alkalmazása mérföldkőnek tekinthetö. Ezek a modellek egy-egy térség, régió ágazati szerkezetének és területi folyamatainak elemzésére, elörejelzésére és a vizsgált területegységek közötti összefuggések jellemzőinek, erősségének meghatározására tettek kísérletet. Az 1950-1980 közötti időszak - elsősorban nemzetközi - szakirodalmában bőségesen találunk nagy részletességgel kidolgozott regionális input-output modelleket, de ennek a korszaknak a hazai szakirodalmában is fellelhetünk néhány ilyen típusú elemzést.

A területi szerkezet vizsgálatát azonban más módszerekkel is megkísérelhetjük. Jelen tanulmány a területi fejlődés szimulációs eljárással történő elemzésének kísérletéról, tapasztalatairól számol be. Ismerteti a szimulációs modell előnyeit és hátrányait, a szimuláció folyamatát, valamint a Közép-dunántúli régióra és a régió három megyéjére kidolgozott kísérleti modell felépítését.

Ez a módszer alkalmas komplex rendszerek elemzésére, aminek következtében a területi folyamatok sokkal árnyaltabb elemzésére ad lehetőséget, mint az idősoros statisztikai módszerek. Bár a tanulmányban bemutatott modell kísérleti jelleggel készült és csak próbafuttatásokat végeztünk rajta, az eredmények és a tapasztalatok a módszer területi kutatásokban való alkalmazására nézve kedvezőek. A jövőben a szimulációs modell ígéretes felhasználási területe lehet az európai uniós források, az állami és magán beruházások területi hatásainak számbavétele, valamint a monitoring rendszerek kidolgozásánál való alkalmazása. 


\section{Területi input-output modellek}

Az input-output modellek az 1950-60-as években élték virágkorukat. Bár az első ilyen, a gazdasági összefüggéseket számszerüsítő modellt a módszer kidolgozója, Leontief már 1936-37-ben összeállította, szélesebb körü elterjedéséhez a számítógépek fejlődésére és a tudományos kutatásban való alkalmazásukra volt szükség. Leontief első modelljét Amerikára dolgozta ki, s magáért az input-output elméletért 1973-ban Nobel-díjjal tüntették ki (Augusztinovics 1996; Bródy 2005).

A magyar nyelven ágazati kapcsolatok mérlegének keresztelt eljárás segítségével meghatározható a gazdasági ágazatok közötti közvetlen és közvetett kapcsolatok iránya és erőssége, s ennek alapján az ágazatok közötti kapcsolatok egész, komplex rendszere felállítható. Egy-egy ilyen modell tetszőleges területi egységre - régióra, országra, de elméletileg akár az egész világgazdaságra is - vonatkozhat, ám a gyakorlati megvalósítást a rendelkezésre álló adatok nem megfelelő szerkezete és nem kielégítő részletessége gyakran korlátozza (Rechnitzer 1984a; 1984b; Augusztinovics 1996; Bródy 2005).

$\mathrm{Az}$ ágazati kapcsolatok mérlege a területi elv, az ágazati elv, illetve mindkét elv együttes alkalmazásával is elkészíthető, ám az így kapott modellek más-más kérdések megválaszolására adnak lehetőséget. Az ágazati kapcsolatok mérlegének speciális típusát képezik a - területi és ágazati elvet együttesen érvényesítö - területiágazatközi mérlegek, amelyek egy térség belsö, ágazatok közötti kapcsolatainak elemzését a régióba történő beszállítások és a régióból történő kiszállítások ágazatonkénti elemzésével egészítik ki. Mivel az egyik régió exportja egy másik régió importját jelenti, lehetövé válik a területek közötti kapcsolatok elemzése, a területközi áramlások ágazatonkénti bontásban történő vizsgálata (Rechnitzer 1984a; 1984b).

$\mathrm{Az}$ input-output modell egy régió kibocsátása iránt jelentkező pótlólagos vagy potenciális kereslet tovagyủrüző hatásainak kimutatására, elörejelzésére is alkalmas. Azaz, a modell alapján - az inverz mátrixon keresztül - képesek vagyunk meghatározni a keresletnövekedés által elöidézett kibocsátás-növekedés nagyságát ágazatonkénti bontásban (Armstrong-Taylor 2004) (1. ábra).

Az egyes szektorok outputjainak növekedése minden egyes áttétel után csökken, és nullához konvergál. Ha azonban összesítjük a több körben megnyilvánuló, ám egyre csökkenő mértékủ kibocsátás-növekedést, akkor a keresletnövekedés által kiváltott kibocsátás-növekedés mértéke meghaladja a potenciális keresletnövekedés nagyságát (Armstrong-Taylor 2004). S mivel a keresletnövekedés által előidézett output-növekedés nem egyenletesen, hanem az inverz mátrix értékei szerint oszlik el az ágazatok között, a hatások elỏrejelzésénél számottevő jelentősége van az ágazatok közötti közvetlen és közvetett kapcsolatok ismeretének.

A regionális input-output elemzés kifejlesztése nemzetközi szinten az 1950-es évek elejére tehető, s már ekkor történtek kísérletek interregionális input-output modellek kidolgozására is (Isard-Moses stb.). Az interregionális és multiregionális input-output modellek kidolgozása nagy mennyiségü - gyakran nehezen beszerezhetö - adatot igényel, ezért ezek összeállítására nemzetközi viszonylatban is ritkán kerül sor (Lengyel-Rechnitzer 2004). 
Smahó Melinda : Kísérlet egy régió szimulációs modelljének kidolgozására.

Tér és Társadalom 21. évf. 2007/1. 117-129. p.

Kísérlet egy régió szimulációs ...

\section{1. ÁBRA}

Tovagyürüző hatások: valamely gazdasági ágazat kibocsátása iránti kereslet-növekedés hatása

(The Effects of an Increase in the Final Demand for Sectoral Output)

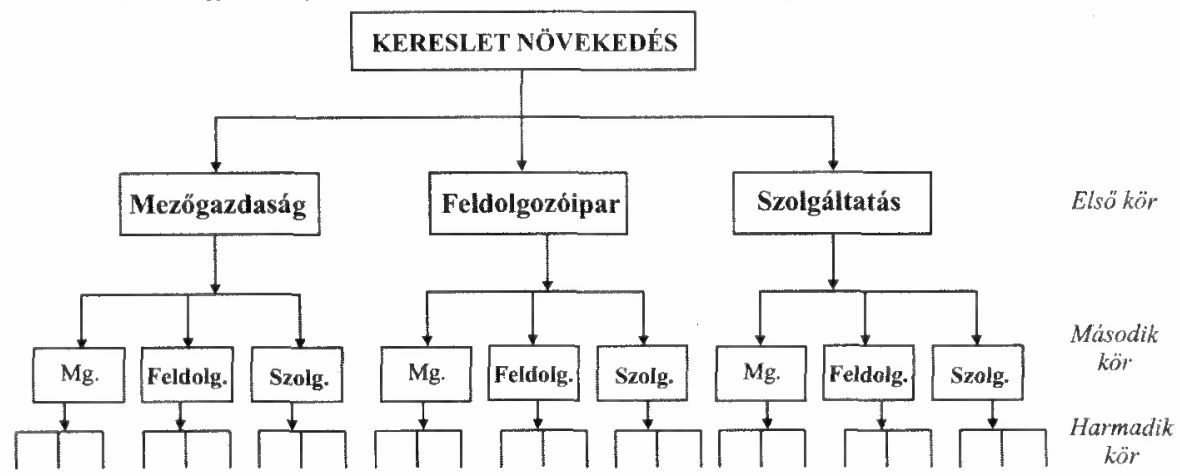

Forrás: Armstrong-Taylor 2004. 42. o. alapján a szerző szerkesztése.

Bár a regionális input-output modellek alapvető és mély gazdasági, illetve területi kapcsolatokat támak fel, alkalmazásuknál az input-output elmélet és a modellezési eljárás korlátait is figyelembe kell venni. Ezek között meg kell említeni az adatigényességet, a kérdőíves és nem kérdőives adatgyüjtés nehézségeit és költségeit, valamint az adatfeldolgozás problémáit (Richardson 1973). Az adatok hozzáférhetösége szempontjából az input-output modellek kis regionális gazdaságokra viszonylag könnyen alkalmazhatók. További hátrány azonban, hogy - megfelelö adatok hiányában - a regionális modellekben is a nemzeti technológiai mátrix alkalmazására kerül sor, holott a technológia régiónként változhat. Hasonló probléma merül fel az import vonatkozásában is, mivel a nemzeti adatok használata alábecsüli az adott régió import függőségét. Ez könnyen belátható, hiszen egy nemzetgazdaság kevésbé függ a behozataltól, mint egy régió. Egy-egy felállított modell torzítja a valóságot annyiban, hogy állandó skálahozadékot feltételez. Ezzel szemben a modell kétségtelenül nagy előnye belső konzisztenciája és elörejelzésre való alkalmassága (Armstrong-Taylor 2004).

A modell szélesebb körủ elterjedésére, későbbi alkalmazására jó példa Carlberg regionális növekedési modellje, amelynek felállitása során multiregionális inputoutput elemzést is végzett, s az 1960-1970 közötti évekre összeállította a Német Szövetségi Köztársaság tartományainak input-output táblázatait. Sikerült bebizonyítania azt a hipotézisét, miszerint minél nagyobb népességủ egy tartomány, annál inkább hasonló a tartományi és a szövetségi technológia. Állítását egyrészt azzal magyarázza, hogy egy nagyobb térségben több jószágot állítanak elö, amihez többféle technológiát alkalmaznak. Másrészt pedig megállapítja, hogy a nagyobb térségek, aggregált régiók és a szövetségi szint közötti technológiai hasonlóság részben a térségek összefüggéséböl, kapcsolataiból (export, import) származik, s ezt regionális input-output modell segítségével sikerült kimutatnia (Carlberg 1978). 
Magyarországon elméleti és/vagy gyakorlati szinten olyan kutatók foglalkoztak ágazati kapcsolatok mérlegével, illetve regionális input-output modellekkel, mint Kornai János, Bródy András, Augusztinovics Mária, Csepinszky Andor, Wirth Gyula, Sikos T. Tamás, Rechnitzer János és mások. Kornai János és munkatársai a távlati tervek megalapozásához végzett kutatásaik során alkalmazták az ágazati kapcsolatok mérlegét az 1960-1970-es években (Kornai 1973). A területi modellek közül talán a legismertebb a Csepinszky-Kovács-Novák szerzöhármas által Vas megyére kidolgozott mérleg, valamint a Fodor-Illés-Bonár-féle, központi körzetre vonatkozó modell. Rechnitzer János 1975. évre készített mérlege Baranya megye területi és ágazati kapcsolatait tárja fel. A területi és ágazati kapcsolatok feltárásából kifolyólag ezek a modellek alkalmasak voltak a térségek, régiók terveinek - az akkoriban uralkodó ágazati szemléletnek megfelelö -, fejlesztési elképzeléseinek kidolgozására és összehangolására, a fejlesztések várható, előre látható következményeinek meghatározására (Rechnitzer 1984a).

Az 1960-70-es években még divatos, nagy méretü, lineáris input-output modellek és azok regionális változatai napjaink szakirodalmában már csak elvétve fordulnak elö. A kilencvenes években még akadt néhány példa az alkalmazásukra, gondolok itt egy-egy kisebb sziget gazdaságának elemzésére vagy a külföldi egyetemi hallgatók által a választott egyetem régiójának gazdaságra gyakorolt multiplikátor hatások mérésére. A Shetland-sziget esetében McNicoll (1984) az Északi-tengeri olajnak a sziget gazdaságára gyakorolt hatását próbálta kimutatni, míg a Western szigetekre készített modelljének célja a turizmus jelentőségének érzékeltetése volt a többi helyi iparághoz viszonyítva (Armstrong-Taylor 2004).

A szórványosan elöforduló alkalmazások ellenére az a tendencia érvényesül, hogy az input-output modellek szerepét fokozatosan az - elsősorban többszektoros makroökonómiai elemzéseknél használt - általános egyensúlyi modellek (computable general equilibrium model, CGE) veszik át. Az input-output modellre jellemző mátrix szemléletü kapcsolat-ábrázolások társadalmi elszámolási mátrixok (Social Accounting Matrices) formájában élnek tovább. Az input-output elemzés alapját jelentỏ ágazatközi áramlásokat azonban mindkét említett, napjainkban használt modell tartalmazza. A számítástechnika és a matematika számottevő fejlődésének köszönhetően további elörelépést jelent a valóságot jobban közelítő nemlineáris modellek kezelésének és megoldásának lehetővé, illetve egyszerübbé válása is (Augusztinovics 1996; Zalai 1998; Hüttl 2003).

\section{A szimuláció elméleti háttere}

A gazdasági és társadalmi folyamatok komplex elemzésénél gyakran találkozunk olyan, sztochasztikus függőségi viszonyokkal, amelyek nem írhatók le analitikus modellekkel. A bonyolult rendszerek analitikus leírása számos egyszerüsítő feltétel beépítését követeli meg, amelyek megbízhatatlanná és felhasználásra alkalmatlanná teszik a modellt. 
A komplex rendszerek elemzésére alkalmas módszerek egyike a szimulációs eljárás. A szimulációs eljárás a sztochasztikus kapcsolatok és az időbeliség problémáját egyaránt kezelni tudja, azaz a sztochasztikus kapcsolatok erösségének meghatározására és elörejelzésre is használható. A szimulációs modell egy időben változó, valós rendszer müködését utánozza. A modell a rendszer múködésével kapcsolatos feltevések halmazából áll, amelyeket a rendszerben szereplö releváns objektumok közötti matematikai és logikai összefüggésekkel fejezünk ki. A szimuláció egy valós rendszerből vett mintavételi kísérletnek tekinthető, amelynek eredményei mintavételi pontok. A végső becslés jóságát a mintavételi pontok száma mellett a kezdeti feltételek, a szimulációs időszak hossza és a modell pontossága befolyásolja (Winston 2003).

A szimulációs eljárás előnye, hogy elmélete viszonylag egyszerü, s a modell könnyen alkalmazható. A szimulációs modell kevés egyszerüsítő feltételt tartalmaz, aminek következtében az analitikus modelleknél sokkal rugalmasabb, így a valós rendszereket is nagyobb megbízhatósággal reprodukálja. Gyakorlati alkalmazásának legnagyobb elönye, hogy a modell a valós rendszeren való kísérletezés kockázata nélkül kipróbálható, és ennélfogva alkalmas a tervezett intézkedések hatásainak kimutatására. Egy felépített szimulációs modell több alkalommal is hasznosítható, különböző stratégiák, paraméterek, tervek hatásainak kimutatására alkalmas. A modell bemeneti adatainak megváltoztatása lehetőséget ad a "mi lenne ha" típusú kérdések megválaszolására. A szimulációs eljárás alkalmazásának hátránya, hogy a modell felépítése, a szükséges adatok összegyüjtése költséges. A döntések hatásainak megbízható elörejelzéséböl, s ily módon az esetleges rossz döntések kiszüréséből származó - pénzben is kifejezhetö - előnyök azonban a modell gyakorlati hasznosítása esetén rendszerint felülmúlják az eljárás költségeit (Winston 2003).

\section{A szimuláció folyamata}

A szimuláció folyamata a cél meghatározásával, a megválaszolandó kérdések, hipotézisek megfogalmazásával kezdődik, valamint a változók és a modellparaméterek is ebben a lépésben kerülnek definiálásra. A folyamat következő lépése az adatgyüjtés és a modellalkotás, amelynek során matematikai, logikai relációkkal adjuk meg a rendszer leglényegesebb tulajdonságait. A modellt ezután olyan formára hozzuk, hogy számítógéppel megvalósítható legyen: itt kerül sor a számítógépes program elkészítésére és az esetleges adathiányok pótlására, mivel a szimulációs modell hiányos adatbázissal nem inűködik. A számítógépes program megírása a modell mérete és komplexitása miatt viszonylag hosszú időt vesz igénybe. Miután elkészült a modell, elsőként ellenőrizzük, hogy elképzeléseinknek megfelelően mủködik-e (igazoló fázis), és ha ez beigazolódott, akkor jóváhagyjuk, ellenkező esetben pedig módosítjuk a modellt. A modell helyességének igazolása és a modell jóváhagyása nem könnyü feladat, hiszen az eredményeket nem tudjuk összevetni más adatokkal, mindössze a változók között definiált kapcsolatok helyessége és a modell által kiszámított eredmények realisztikussága jelenthet támpontot (Winston 2003). 


\section{2. ÁBRA}

A szimulációs modell felépitésének lépései

(Flowchart of the Simulation Model)

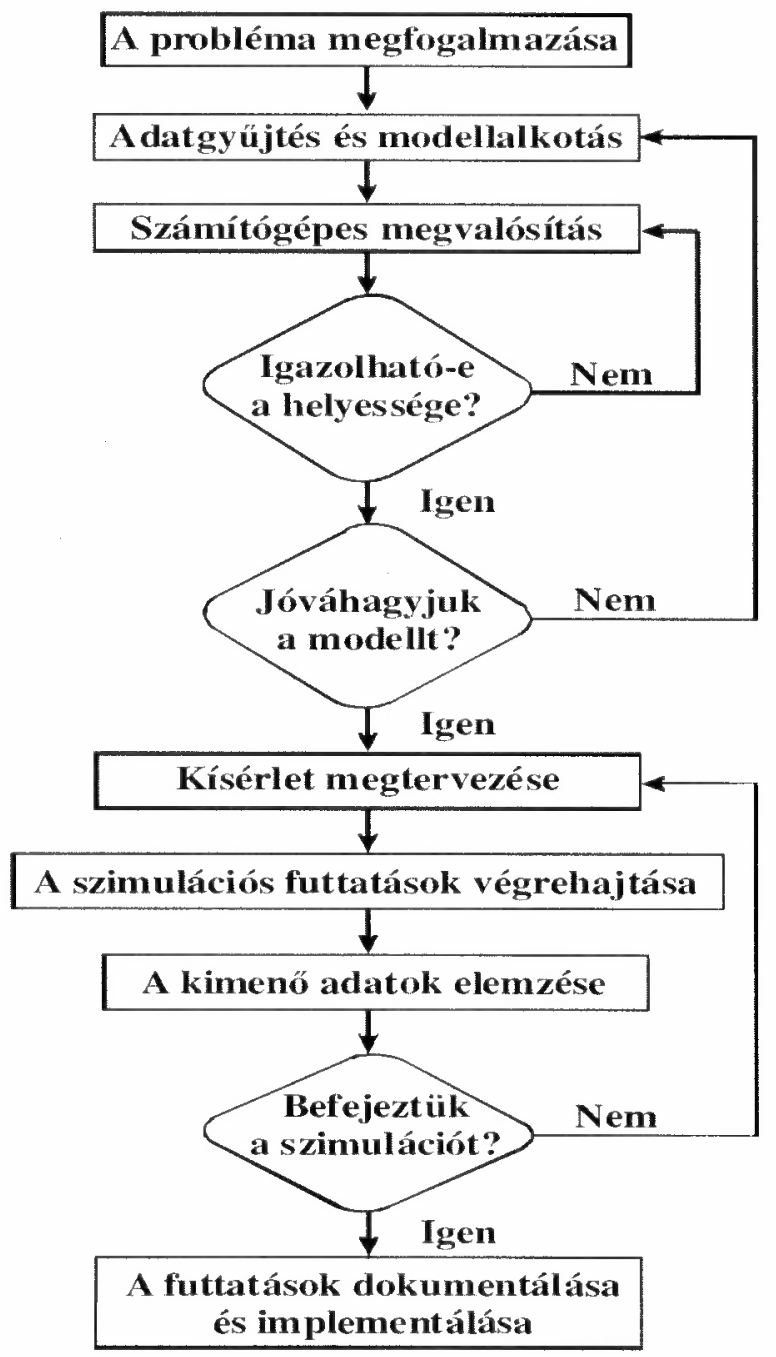

Forrás: Winston 2003. 1114. o.

Amennyiben a modell mủködését - az esetleges átalakítások után - megfelelónek találjuk, elkezdödhetnek a futtatások (szimulációs kísérletek). A különbözö adatokkal végzett futtatások eredményeit rögzítjük, dokumentáljuk és elemezzük. A modell az adatbázis alapján feltárja a változók közötti sztochasztikus kapcsolatok erósségét (súlyrendszer), majd ennek ismeretében elörejelzést készít. A bemeneti adatok módosításával kimutathatóvá válik egy-egy tényező változtatásának hatása, s így választ tudunk adni a „mi lenne ha” típusú kérdésekre (Winston 2003). 
Smahó Melinda : Kísérlet egy régió szimulációs modelljének kidolgozására.

Tér és Társadalom 21. évf. 2007/1. 117-129. p.

\section{A területi fejlödés elemzése szimulációs modellel ${ }^{l}$ \\ Ámodell felépitése}

A szimulációt, mint elemzési módszert több tudományterületen alkalmazzák, elsösorban olyan esetekben, amikor a valós rendszeren történő kísérletezés nagyon költséges lenne, felbecsüllhetetlen károkat okozna, vagy az eredeti állapot visszaállítása nem lehetséges. Így a mủszaki tudományoktól az orvostudományokon keresztül egészen a társadalomtudományokig találkozhatunk szimulációs modellekkel. Kutatásunk során a területi fejlödés szimulációs modellel történő elemzésére tettünk kísérletet, a Közép-dunántúli régiót, illetve annak három megyéjét (KomáromEsztergom, Fejér, Veszprém) tekintve mintatérségnek.

A modellezéshez olyan adatbázis felépítésére volt szükség, amely tartalmazza a kiválasztott megyék/régió fejlettségét leíró, valamint az adott területi egység fejlödésére ható tényezőket. A területi fejlödés leírására általános, gazdasági, oktatási, infrastrukturális, egészségügyi és környezetvédelmi mutatócsoportokat állítottunk össze a három megyére és a régióra vonatkozóan. Az eredeti adatbázisban 50 mutató szerepelt, amelyek közül hatot ágazatonkénti bontásban gyüjtöttünk össze, $s$ így az adatbázis 136 sorból állt, s több mint 3800 adatot tartalmazott. A hat gazdasági mutató ágazatok szerinti részletezésével a modell eredményeinek pontosságát kívántuk javítani, hiszen az egyes szektorok a különböző területi egységekben eltérő súllyal vannak jelen.

Az adatok összegyüjtésénél a Központi Statisztikai Hivatal forrásaira (Stadat, Területi Statisztikai Évkönyv, Kommunális Évkönyv, Magyarország nemzeti számlái) és az APEH adatbázisaira támaszkodtunk. Mivel a szimulációs modell a múltbeli adatok összefüggéseit vizsgálva határozza meg a változók jövőre vonatkozó értékeit, az adatbázis összeállításánál a kijelölt mutatók minél hosszabb idősorának felállítása volt a cél. Megfelelö részletességủ adatok azonban csak az 1990-es évek közepétöl állnak rendelkezésre, így az adatbázis idödimenziója az 1996-2002 közötti idöszakra terjed ki. Ebben az időintervallumban az esetlegesen hiányzó értékek az egyes mutatók adataira illesztett trendfüggvény segitségével kerültek meghatározásra. Erre a lépésre azért volt szükség, mert a modell hiányos adatsorok esetén nem müködöképes.

$\mathrm{Az}$ adatbázis elsỏ változatának elkészítése után különféle korrekciók végrehajtása vált szükségessé. A legradikálisabb változtatást az adatbázis redukálása jelentette, amelynek során az eredeti mutatókból egy reprezentatív részhalmaz került kiválasztásra. Ennek egyrészt technikai okai voltak (az egész adatbázis modelljének szimulációs futtatása olyan hosszú időt vett volna igénybe, amely a kutatási feladatmegoldás alatt nem kivárható), másrészt a túl nagy modell átláthatatlansága emberi szempontból okozhatott volna gondot. Az ágazati bontásban rendelkezésre álló mutatók esetében a modellbe bekerülő ágazatok számát is csökkentettuk, így a 15 ágazat helyett öt szektor (ipar; építöipar; szálláshely-szolgáltatás, vendéglátás; ingatlanügyletek, gazdasági szolgáltatás; közigazgatás, védelem, társadalombiztosítás) értékei maradtak az adatbázisban. A redukciót követően az adatbázis 62 sorból állt, és 29 mutató adatait tartalmazta. Az adatbázis azonban még így is nagynak bizonyult a 
modellezéshez, ezért az ágazati bontásban rendelkezésre álló mutatók számát ismételten csökkentettük oly módon, hogy a továbbiakban csak az ipari ágazat adatait, valamint az ágazatok összesített értékeit szerepeltettük a modellben. Az adatbázis kétszeri szükítése után végül az l. táblázatban látható mutatók kerültek be a modellbe.

$\mathrm{Az}$ adatbázis szerkezetének átalakításán túl a forintban kifejezett mutatók értékein is korrekciót hajtottunk végre, az adatokat 1996. évi árszintre hoztuk. Erre az árszínvonal-növekedés hatásának kiszürése miatt volt szükség, ami a közgazdasági értelmezhetöség mellett azért is fontos volt, mert az évröl évre (jelentös mértékben az árszínvonal-emelkedés miatt) növekvö értékek megtéveszthetik a modellt, és téves következtetésekhez vezethetnek (hiszen a modell nem tudja kezelni az inflációt).

A szimulációs modell az adatbázisban szereplő mutatók közgazdasági szakirodalom alapján felállított összefüggésrendszerén alapul. Az egymással gazdaságilag és logikailag összefüggö mutatók értékei közötti kapcsolatok keresésével a modell képes a mutatók egymásra gyakorolt közvetlen és közvetett hatásainak érzékelésére, valamint ezen hatások erősségének meghatározására (súlyrendszer). lly módon a modell a múltbeli értékek alapján feltárt összefüggésekbỏl kiindulva végzi el az elörevetítést. A modellépítés során meg kellett határozni a mutatók közötti kapcsolatrendszereket, valamint ki kellett jelölni azt a néhány mutatót (inputot), amelyeknek a megváltoztatásából adódó hatásokra kíváncsiak vagyunk (változtatandó input, I). Ezek a változók csak inputként szerepelnek, s a modell segítségével megvizsgálható, hogy értékeik módosítása milyen hatásokat vált ki a többi mutató értékében, azok nagyságát hogyan befolyásolja. A nagybonyolultságú rendszernek köszönhetöen a modell nemcsak a közvetlen, hanem a közvetett, tovagyürüzö hatások kimutatására is képes. A szimulációs modell felépítése során a mutatóknak az l. táblázatban szereplö kapcsolatrendszerét vettük alapul.

Az első oszlopban feltüntetett kódok a változók azonosítására szolgálnak, míg a második oszlop a változó típusát jelöli, vagyis azt, hogy csak bemeneti (I) vagy közbenső (I/O) változóként szerepelnek-e. A csak bemeneti változók értékei nem más változóktól, hanem a környezettöl függnek, és ezek a mutatók jelentik az I/O típusú változók bemenetét. Ezzel szemben az I/O típusú változóknak bemenete és kimenete is van, azaz más változóktól függnek, miközben maguk is további változók függvényei, bemenetei (táblázat utolsó oszlopa) (Jávor-Rechnitzer 2004).

A mutatók kapcsolatrendszere alapján például az összágazati beruházások nagysága a külföldi müködő tőke állományával, a GDP nagyságával, a helyi önkormányzatok felhalmozási és tőkejellegủ bevételeivel, a népesség számával, az alkalmazásban állók számával és bruttó átlagkeresetével áll összefüggésben. A K+F ráfordítások nagyságát az ezer lakosra jutó müködő vállalkozások száma, a felsőoktatási intézmények hallgatóinak száma, a beruházások nagysága, a külföldi müködő töke állománya és a GDP nagysága befolyásolja. A modellben az épített lakások száma, a gazdasági ág szerinti beruházások nagysága, az egy fỏre jutó személyi jövedelemadó, a beszerzési áron számított GDP és a decentralizált területfejlesztési támogatások összege szerepel változtatható inputként. 


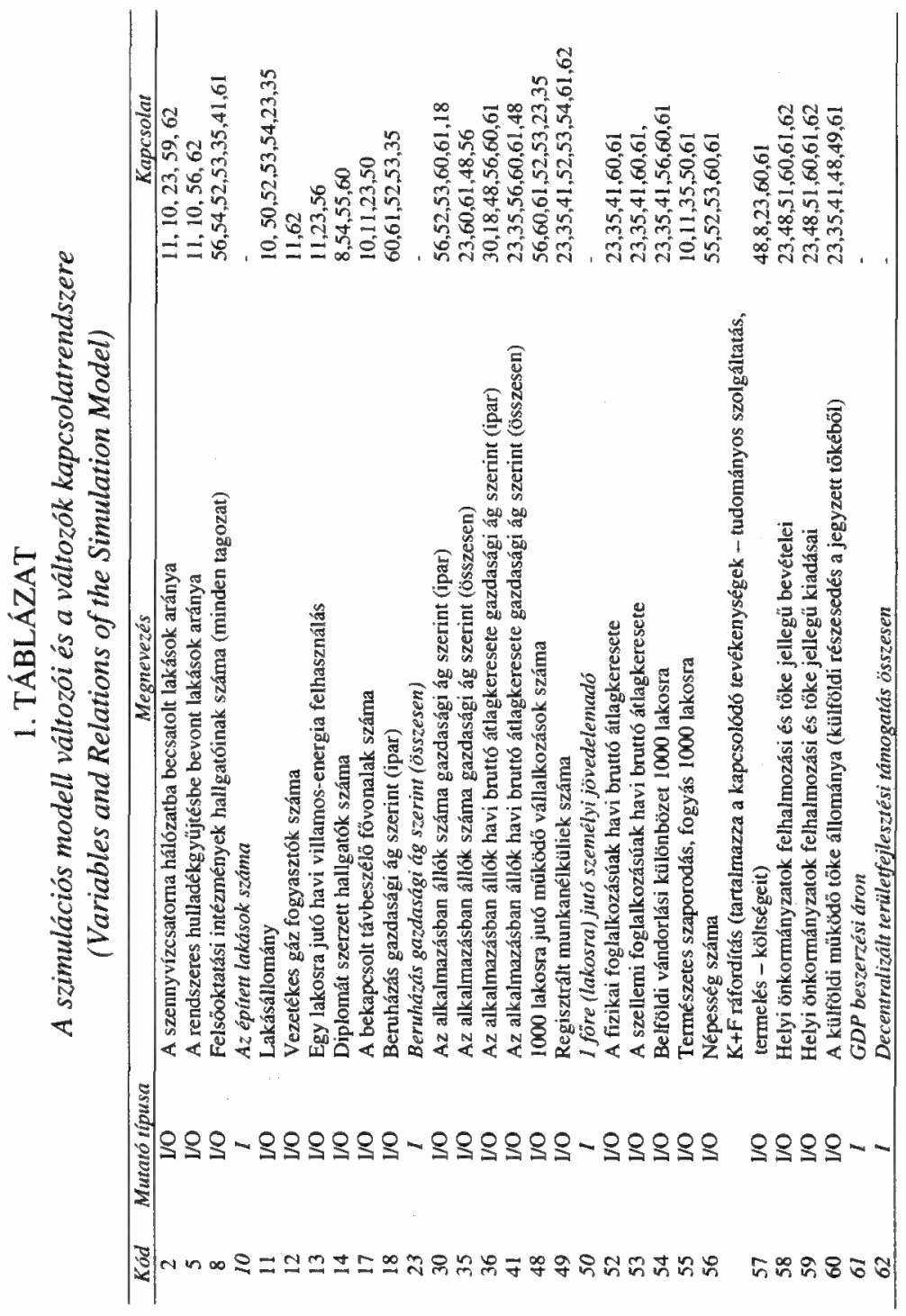

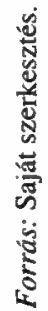


Smahó Melinda : Kísérlet egy régió szimulációs modelljének kidolgozására.

Tér és Társadalom 21. évf. 2007/1. 117-129. p.

A csak input változók realitását a modell nem vizsgálja, ezért a csak bemeneti változók esetében a modell lehetővé teszi, hogy értékeiket megváltoztassuk, és megfigyeljük, hogy a modell többi mutatójának értéke hogyan reagál a változásra $\mathrm{A}$ modell segítségével meghatározható például, hogy a decentralizált területfejlesztési támogatások összegének növelése (a tervezett összegek pontos megadásával) hogyan hat a GDP növekedésére vagy a külföldi múködö töke állományának alakulására stb.

A változók, és a közöttük definiált kapcsolatok alapján felállított modellt mutatja a 3. ábra.

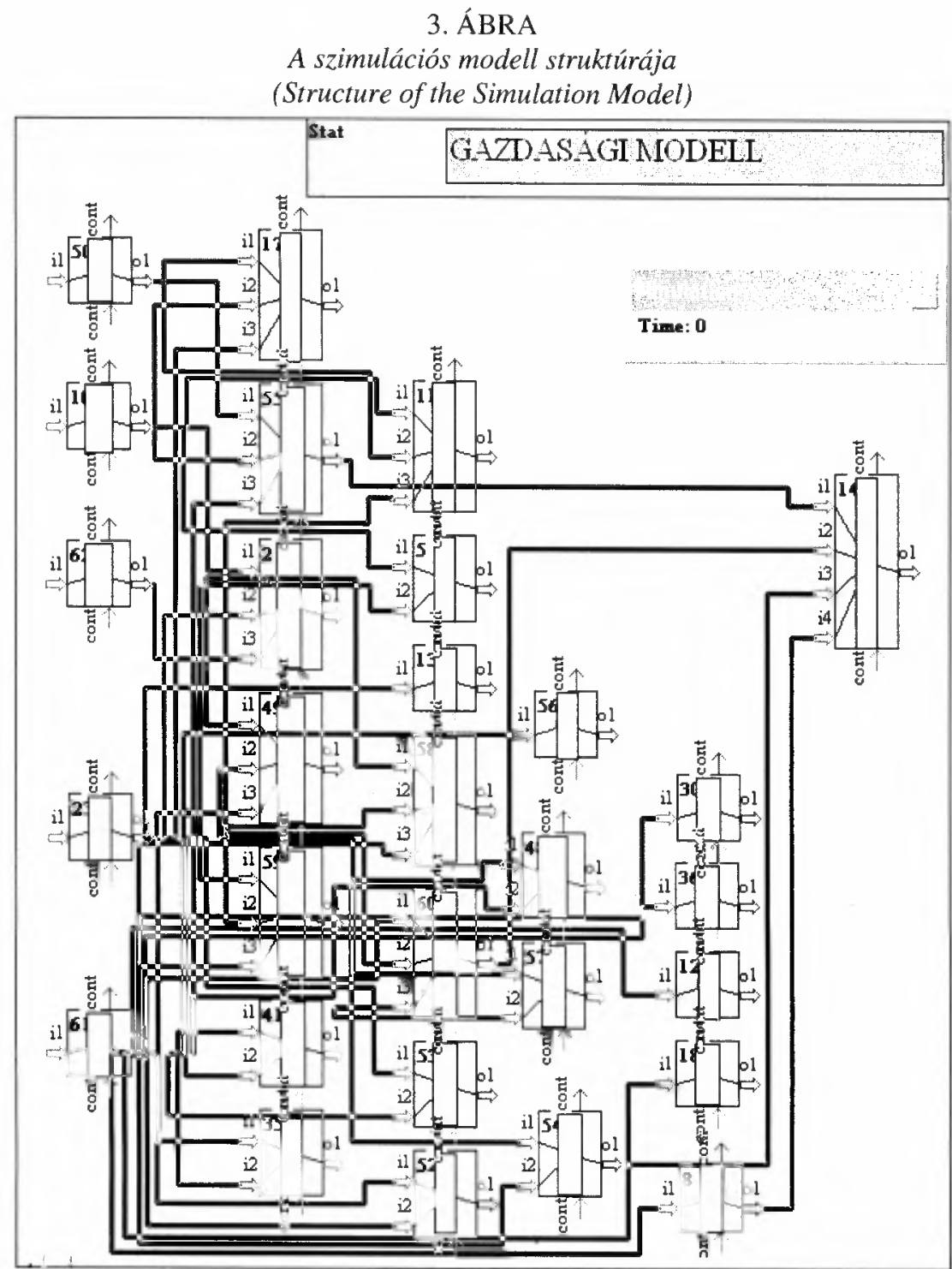

Forrás: Jávor-Rechnitzer et al. 2004. 
Futtatás, elörejelzés, elemzés

A modell felépítését a futtatás követi, amelynek első lépése a rendszert alkotó mutatók értékei közötti kapcsolat keresése. Ennek során a program a megadott kapcsolatok és a tényadatok alapján egy súlyrendszert definiál, amely az egyes mutatók közötti relációk erősségét fejezi ki. Matematikailag úgy zajlik az eljárás, hogy a program az alábbi, a modell jóságához definiált hibafüggvényt minimalizálja, amelyben $\mathrm{m}_{\mathrm{i}}$ az eredeti adatokat, $\mathrm{v}_{\mathrm{i}}$ pedig a modell által kiszámított értékeket jelenti (Jávor-Rechnitzer 2004).

$$
h=\sum_{t=1996}^{2002} \sum_{i=1}^{62}\left\{v_{i}(t)-m_{i}(t)\right\}^{2}
$$

A szimulációs futtatás második lépése az elörevetítés, azaz a korábban meghatározott súlyok felhasználásával a változók jövőbeli értékeinek kiszámítása (JávorRechnitzer 2004). Mivel a súlyok a modellben definiált kapcsolatok és a változók tényadatai alapján alakulnak ki, a szimulációval történő elörevetítés a mutatók öszszefüggéseinek, egymásra gyakorolt hatásainak figyelembevételével megy végbe. A szimulációs eljárással tehát egy egész rendszer komplex előrevetítését tudjuk elvégezni, szemben más elörejelzési módszerekkel, például a trendszámítással, amikor az egyes változók idősoraira külön-külön illesztett trendfüggvények segítségével próbáljuk a mutatók jövőbeli értékeit meghatározni (4., 5. ábra).

\section{4. ÁBRA}

Elörejelzés a változók idösoraira illesztett trendekkel

(Prognosis with Trends)

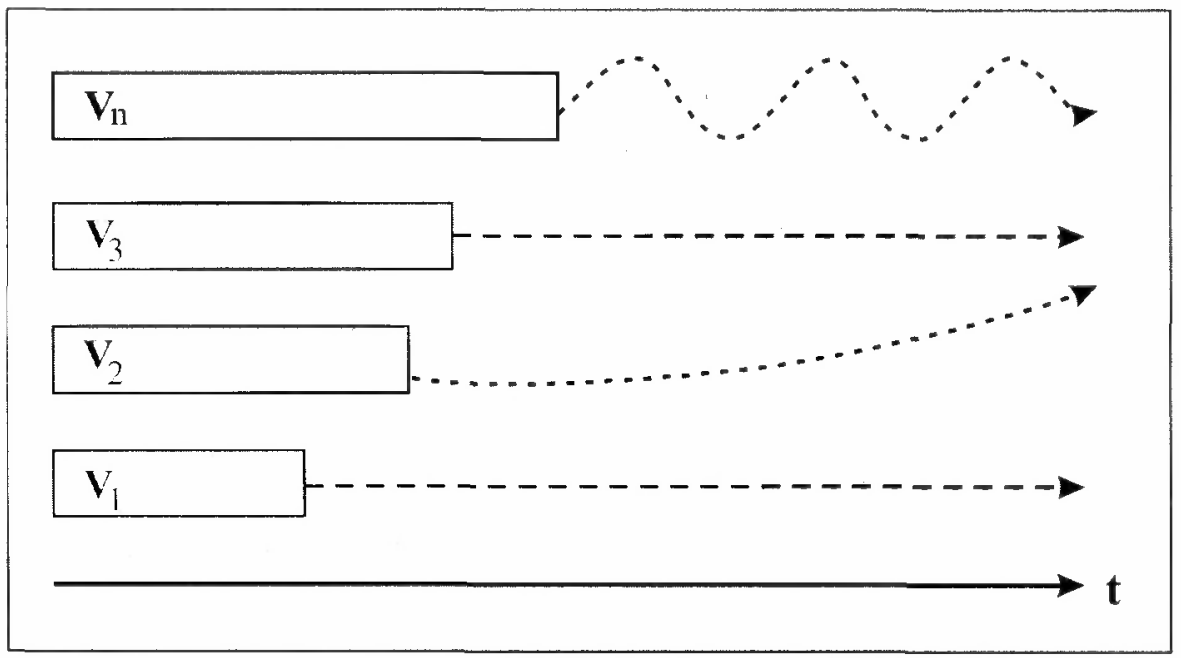

Forrás: Saját szerkesztés. 
Smahó Melinda : Kísérlet egy régió szimulációs modelljének kidolgozására.

Tér és Társadalom 21. évf. 2007/1. 117-129. p.

\section{5. ÁBRA}

A szimulációs modell elörevetítési mechanizmusa (Prognosis with Simulation Model)

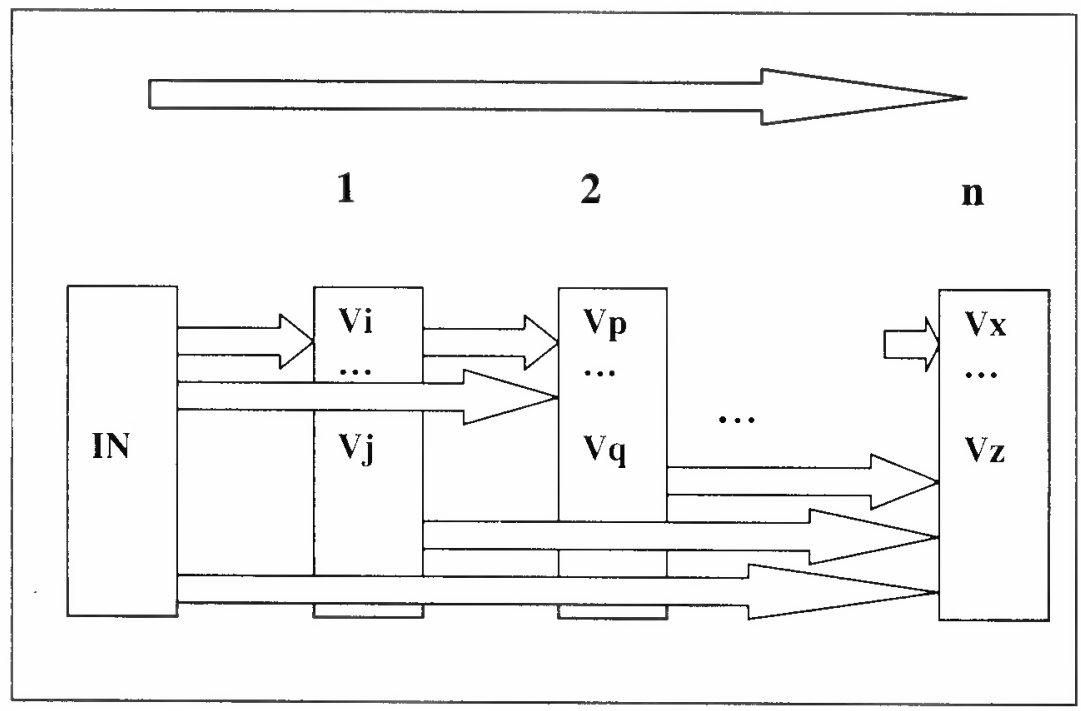

Forrás: Jávor-Rechnitzer et al. 2004.

Bár a szimulációs modell hosszú távú elörejelzésre nem alkalmas, nagy elönye abban rejlik, hogy képes bonyolult összefüggéseket tartalmazó rendszerek értékeinek elörejelzésére, így például az ágazati kapcsolatok figyelembevételével a szektorális adatok elörevetítésére, amiből már meghatározható a jövőbeli ágazati szerkezet. A futtatások és az elörejelzés fázisát a kapott értékek elemzése követi. Az elörejelzés pontosságának, a modell müködésének és alkalmazhatóságának értékelése érdekében célszerủ a modell összeállítása után néhány évvel beválás vizsgálatot végezni, azaz az elöre jelzett és a ténylegesen kialakult adatokat összehasonlítani.

\section{Összegzés}

A regionális input-output modellek és a tanulmányban bemutatott, kísérleti jelleggel kidolgozott szimulációs modell a területi szerkezet elemzésének és előrejelzésének bonyolultabb módszerei. Alkalmasak egy-egy komplex rendszerként kezelt térség, régió elemzésére, s a rendszerelemek között - eltérö módszerrel - definiált kapcsolatoknak köszönhetően a közvetett, tovagyürüzỏ hatások kimutatására. Míg az input-output modellek eredeti formájukban fokozatosan kiszorulnak az elemzésekböl, addig a rugalmasabb felépítésü, sztochasztikus viszonyok kezelésére alkalmas, szimulációs modelleknek a területi kutatásokban és a területi döntések elökészítésében való alkalmazása előtt új távlatok nyílnak meg. Bár a bemutatott modellel csak próba futtatások készuiltek, a kísérlet sikeresnek tekinthetö, s értékes tapasztalatok halmozódtak fel a kutatás során. A modell továbbfejlesztéséhez és gyakorlati alkalmazásához azonban további kutatásokra lenne szükség. 


\section{Jegyzet}

'A bemutatott modell kidolgozására „A szimulációs modell kidolgozása és alkalmazása a területi fejlődés vizsgálatában" címü OKTK kutatás keretében került sor 2004-ben. A kutatásban Dr. Rechnitzer János, Dr. Jávor András, Dr. Szücs Gábor, Mészáros-Komáromi Gergely és Smahó Melinda vett részt. A kollégáimtól - a hivatkozási szabályok betartásával - átvett gondolatokat a kutatási jelentésre történö hivatkozással jelzem.

\section{Irodalom}

Armstrong, H.-Taylor, J. (2004) Regional Economics and Policy. Blackwell Publishing, 3. Edition, 5-63. 0 .

Augusztinovics M. (1996) Miről szól az input-output modell? - Közgazdasági Szemle. Április. 315-320. o.

Bródy A. (2005) Wassily Leontief. - Bekker Zsuzsa (szerk.) Közgazdasági Nobel-díjasok 1969-2004. KJK-KERSZÖV Jogi és Ưzleti Kiadó Kft., Budapest. 137-148. o.

Carlberg, M (1978) Ein interregionales, multisektorales Wachstumsmodell - dargestellt für die Bundesrepublik Deutschland. Vandenhoeck\&Ruprecht in Göttingen.

Hüttl A. (2003) A gazdasági mérés történetérỏl. Adatok, elmélet, gazdaságpolitika. - Közgazdasági Szemle, 164-182, o.

Jávor A.-Rechnitzer (et. al.) (2004) Jávor A.-Rechnitzer J.-Mészáros-Komáromi G.-Smahó M.-Szücs G. (2004) A szimulációs modell kidolgozása és alkalmazása a területi fejlődés vizsgálatában. OKTK kutatási jelentés.

Kornai J. (1973) A gazdasági szerkezet matematikai tervezése. Közgazdasági és Jogi Könyvkiadó, Budapest.

Lengyel I.-Rechnitzer J. (2004) Regionảlis gazdaságtan. Dialóg Campus Kiadó, Budapest-Pécs, 301-324. o.

Rechnitzer J. (1984a) Az ágazati kapcsolatok mérlegének alkalmazása a területi szerkezetek és kapcsolatok vizsgálatában. - Sikos T.T. (szerk.) Matematikai és statisztikai módszerek alkalmazási lehetőségei a területi kutatásokban. Földrajzi Tanulmányok 19. Akadémiai Kiadó, Budapest. 186-218. o.

Rechnitzer J. (1984b) A területi gazdasági szerkezetek és kapcsolatok modellezése. A teruleti inputoutput modellek). A Magyar Tudományos Akadémia Dunántúli Tudományos Intézetének kutatási eredményei. 1981-1985. 10. sz.

Richardson, H.W. (1973) Input-Output and Regional Economics. Weidenfeld and Nicolson, London. Winston, W.L. (2003) Operációkutatás. Módszerek és alkalmazåsok. Aula Kiadó, Budapest. 1073-1120. o.

Zalai E. (1998) Általános egyensúlyi modellek alkalmazása gazdaságpolitikai elemzésekre. - Közgazdasági Szemle. 1065-1081. o.

\section{AN ATTEMPT TO BUILD UP A SIMULATION MODEL OF A REGION}

\section{MELINDA SMAHÓ}

After the great age of regional input-output models in the 1960-1970's, new methods have been appeared in the territorial research. One of this methods is the simulation model that is able to analyse complex systems. The aim of this study is to describe a simulation model that has been created as an attempt to analyse territorial development. 